\title{
Hereditary site-specific ovarian cancer syndrome
}

INSERM

\section{Source}

INSERM. (1999). Orphanet: an online rare disease and orphan drug data base. Hereditary site-specific ovarian cancer syndrome. ORPHA:213524

Hereditary site-specific ovarian cancer syndrome refers to ovarian cancer caused by germline mutations in various genes, usually associated with additional cancer risks. The most common are breast and ovarian cancer syndrome (HBOC) due to mutations in BRCA1 and BRCA2 genes and hereditary nonpolyposis colorectal cancer (HNPCC) due to mutations in DNA mismatch-repair genes. Mutations in ST K11 gene, causing PeutzJeghers syndrome, are also associated with a risk of ovarian cancer (typically sex cord stromal tumors). Mutations in other genes, including RAD51C, RAD51D, PALB2, confer an elevated ovarian cancer risk in a minority of patients. 